\title{
Application of Information and Communication Technology (ICT) in Information Dissemination in Special Libraries in Nigeria
}

\section{Mohammed Lawal Akanbi, Dorcas Odunayo Ogunleye, Kabir Alabi Sulaiman}

University of Ilorin, Ilorin

\section{Abstract}

Background of the study: This study examined the Application of ICT in Dissemination of Information in Selected Special Libraries in Ilorin Metropolis, Kwara State, Nigeria. Three Special libraries from the metropolis of the state comprised the sample population of the study; Central Bank of Nigeria Library, Michael Imoudu Institute of Labor Studies Library and Ghalib Chamber Library.

Purpose: The study employed a survey research design using the Enumeration sampling technique. A questionnaire was used to obtain data from the respondents. The population of the study consisted of twenty-one (21) respondents which comprised of library professionals and library assistants. The usage of Email to render CAS is not a norm in these special libraries.

Method: Data collected from the field were analyzed using descriptive method of analysis.

Findings: Apart from CAS, it was found that selective dissemination of information (SDI) is not done with the aid of technological tools in these Libraries and these libraries rarely make use of OPAC to provide easy access to their resources, efficiency and effectiveness of ICT in the dissemination of information were not realized because of the low usage of ICT to drive operations in the library. The study recommended that there should be a standard alternative source of power for proper Usage of ICT facilities and management of special libraries should help their users in subscribed for a database that would assist them in having access to robust information.

Conclusion: The study concluded that ICT facilities are put in place in the selected special libraries are not adequate and are as well not fully utilized. It was gathered that the usage of ICT facilities to render services like current awareness services (CAS) is not up to expectation.

Keywords: Special Library, Information and Communication Technology, Application of ICT, Current Awareness Services, Selective Dissemination of Information.
Paper Type:

Research Paper

Submitted: 21 June 2019 Accepted: 11 September 2019

* Correspondence: Mohammed Lawal Akanbi

E-mail: lawal.akanbi@yahoo.com 


\section{Introduction}

Information and communication technology (ICT) refers to all technologies used to handle telecommunications, broadcast media, intelligent building management systems, audiovisual processing and transmission systems, and network-based control and monitoring functions. Rana (2009) opined that ICT holds the key to the success of modernizing information services. Applications of ICT are numerous, but mainly it is used in converting the existing paper-print records in the entire process of storage, retrieval and dissemination. Information and Communication Technology (ICT) infrastructure is an important resource of a modern library or information center. ICT is the electronic means of capturing, processing, storing and communicating information. Chandler, Daniel, Munday and Rod (2012) notes that ICT is the study, design, development, application, implementation, support or management of computer-based information systems. The term is commonly used as a synonym for computers and computer networks, but it also encompasses other information distribution technologies such as television and telephones. Ifuekoet al.,(2011) also presented a definition that ICT is the digital processing and utilization of information by the use of electronic computers. It comprises of the storage, retrieval, conversion and transmission of information.

Library professionals need distinct information tools (Information and Communication Technology) for daily routine tasks as well as for research and academic activities and ICT has contributed immensely to the performance of the professionals in the discharge of their duties such as cataloguing, reference services, circulation management, serials control, etc. Information and Communication Technologies are being increasingly used in library and information services for the acquisition, processing and dissemination of information (Madu\& Azubogu, 2017). Librarians also update their knowledge using information and communication technology (ICT) in order to successfully undertake their roles of being responsible for validating the library (Bilawar, 2013). The latest devices for information and communication technology have resulted in the rapid circulation of knowledge and have transformed the information handling activities in research and libraries all over the world. The emergence of modern library advances in ICT has opened up new ways of accumulating, regulating and disseminating scientific and technical information and this resulted from changing routine tasks by using effective and efficient technologies to intensify and integrate their electronic resources and services (Murray, 2013).

Libraries and information centers have been using ICT based resources and services to satisfy the diverse information needs of their users. However, these resources and services are not utilized fully. Under-utilization of these resources and services has been a cause of concern to librarians worldwide (Mamman, 2015). The use of information and communication technologies has become increasingly important in special libraries. Special libraries are switching over to ICT based resources and services at an accelerated pace. E-journals, CD-ROM databases, online databases, ebooks, web based resources and a variety of other electronic resources are fast replacing the traditional resources of special libraries (Make, 2008).

\section{Statement of the Problem}

It is misleading to assume that the introduction of ICT in Library services provides perfect and trouble-free information management possibilities. Nigeria, like majority of developing countries, is an "information-poor" country that is lacking behind in the use of ICT. The scarcity of published current information is particularly found in the information area, which is still in infancy. Considering the enormous benefits that are experienced in the impact of ICT in libraries, they still experience some obstacles or hindrances in the effective and efficient use of the ICT resources and they are administration barriers, lack of shared initiatives, the issue of phobia, lack of appropriate technical skills and inadequate infrastructural facilities.

The consequences of not applying ICTs in special libraries are that they will deny users access to the full range of information available through newer technologies and their services will not meet 
the needs of users. As a result, users may not be satisfied. Similarly, they would not be able to achieve organizational objectives and goals as the special libraries are mostly embedded in organizations serving a specialized clientele. This study, therefore examined the application of ICTs in selected special libraries in Ilorin, Kwara State and its impact on their information dissemination to its users.

\section{Research Questions}

- What is the level of application of information communication technology in the dissemination of information on the selected special libraries in Ilorin, Kwara state?

- What are the analyzed specific factors that promote or hinder the use of ICT based equipment on the selected special libraries in Ilorin, Kwara state?

- What are the efficiencies and effectiveness of ICT in the dissemination of information on the selected special libraries?

- What are the challenges associated with the application of ICT in the special libraries in Ilorin, Kwara state?

- What are the contributions of ICT to the provision of information about the selected special libraries in Ilorin, Kwara state?

\section{Literature Review}

The term "special libraries" encompasses a wide range of library types which do not fit comfortably into other categories of libraries such as a public or academic library. Although some of the special libraries are open to public, yet they are not considered to be public libraries because they do to contain general information covering a wide range of subjects or topics. According to the Special Library Association's Association Fact Sheet, a special library is a place where information is evaluated, analyzed, organized, packaged, and presented in a manner that "maximizes its usefulness." Williams (2007) defines it as "often times they are a place where members of the parent organization turn to for very specific and very subject specific answers.

Special libraries have been in existence for over a century, however, the concept has not yet been clearly defined and many opinions as to what exactly special libraries entail still prevail. Special libraries serve a very specific clientele which in most cases are a very small group of users with very specific requirements. Similarly, the libraries have highly specialized collections which concentrate on a specific subject, field or format (Asghar, Mahe \& Shafique, 2012). Special library fields like; Business, Industry, Research and Scientific Organizations, Government Departments, Corporate Sector, Agriculture, Law, Medicine, Chemistry, Engineering, Social Science, History, Advertisement, Insurance, Military, Music, Theology and News fields, etc. This examines the roles of the special library and its relation to its institutional activities, and is therefore mainly focused on making knowledge and expertise available to further achieve the institution's goals. The service delivery of these libraries is based on the following according to the Poll (2007): a collection that is tailored to suit the needs of the clientele, collections and services that consider current needs more than possible future needs, the speed and accuracy of reference services proactive delivery of relevant information to users, customized user services (personal profiles, alerting services, selective dissemination of information), efficient background services and cost-efficiency of services.

The concept of ICT is made up of three variables; Information, Communication and Technology. Bitagi (2013) defined the term as news that comes to the receiver for the first time, and which enables the receiver to take action according to expectation. KOC University Library Glossary (2014) states that information is data presented in readily comprehensible form, to which meaning has been attributed within a context for its use. Communication, on the other hand comes from a Latin word "communicate" which means to 'to share' 'to make common' (Rosengren, 2000). Communication is referred to as the imparting or exchanging of information by speaking, writing or using some other medium. In simple terms, it is the act of transferring information from one place to another. 
Technology, the third element, is derived from the Greek word 'teklie,' which refers to the art of craft, and 'Logia,' meaning an area of study; thus the technology is the scientific study and the use of applied sciences or the application of sciences for the purpose of transforming natural resources and endowments into goods and services (Brey, $2009 \&$ Volti, 2009). The definitions of ICT are based on the diverse views as proposed by different researchers. Make (2008) posited that ICT is all about technologies that aid in the communication process of passing messages from the sender to the receiver. Okenwa (2008) concludes that technologies have advanced the development of communication and multimedia equipment that are capable of accepting data, processing data into information and storing both the data and information for future use and reference purposes.

Daintith (2009) explains ICT to mean a branch of Engineering dealing with the use of computers and telecommunications equipment to store, retrieve, transmit and manipulate data. The British Northern Examination Association (BNEA) (2001) defined ICT as "the study of information handling and its use in the society by means of modern technology. This includes the acquisition, processing, storage and communication of information in any form by appropriate means". The role of Information and Communication Technology in achieving institution's or organization's strategic goals has been of tremendous importance in improving the services provided by libraries because of the inability of the existing traditional manual methods to cope effectively and efficiently with the increasing volumes in the library.

Dissemination refers to the distribution of information to the users. This information could be of any type and its subtypes. According to the Routledge (1997) International Encyclopedia of Information and Library science, the dissemination is the "active distribution and the spreading of information of all kinds are called dissemination of information. It concerns metadata as well as primary sources (Routledge, 1997)". To disseminate in the field of communication means to broadcast a message to the general public without direct feedback from the audience. Literature growth in knowledge domain has great impact on every sphere of life especially in professional activities. This too has a visible on librarianship profession, especially in library services. This tremendous growth has put the information service providers in collection, processing and dissemination of desired information. At the same time the role of librarianship "right information to the right user at the right time" is to be retained, despite the knowledge explosion in every discipline.

The adoption of ICT has revolutionized service provision in libraries, their general information management systems and led to the transformation in the way we manage information in the information age. Special libraries provide a client focused library and information service. Their staff obtains, organize, and provide access to selected, current and authoritative information sources for their organization. The library staff uses information resources and communication technology to facilitate effective and efficient client access to information that support the objectives and goals of their parent institution. The application of ICThas enhanced accessibility to information worldwide and as a result of the invention of the internet and through it, wide-angle information materials are made available in various formats thereby increasing accessibility to information.

Ramzan and Singh (2009) observed that easy integration of various library activities, increases efficiency in the acquisition, access to data, cataloguing, classification, information retrieval and dissemination. It eliminates/reduces repetitive work; helps avoid duplication of information resources; increases the range of services; provide marketing opportunities; facilitates cooperation and the formation of networks and resources sharing in libraries. Madu (2004) noted that with the application of ICT in special libraries, easy access of collection of other libraries using the network can be done. In addition, Mamman, (2015) observed that the application of ICT in special library operations also reduces the tedious and energy-sapping tasks associated with manual operations in the library. It enables special library staff to reduce repetition, drudgery and time consuming clerical activities such as typing, recordkeeping and accounting. He also observed that the result of applying ICT in special library operations is that the library staff will have more energy 
and time, which can be used to attend to more library patrons and perform more professional duties. Special libraries are known to be attached to organizations that place emphasis on the need for steady strategic information to facilitate their steady expansion and growth. Most organizations and institutions are therefore employing (ICT) as a tool for competitive advantage to support the accomplishment of their objectives. ICT has to be made an addition to special libraries and a critical component towards supporting the provision of effective information services to the parent organization (Madu \& Azubogu, 2017). The future of library and information services is bound up closely with the development of ICT, as many of its activities and services can be enhanced and many new services such as services such as resource sharing, digitized circulation system, current awareness services, information subscriptions and ordering, acquisition of information materials, creation, and management of databases, electronic mail services, publications, selective dissemination of information and information storage have been developed using suitable ICT in an appropriate way (Maness, 2006).

Despite ICT vitality and its potentials for enhancing service and operations, the fact that ICT has been found to be an essential tool in information services delivery there are obstacles which hamper the effective utilization of ICTs in libraries. There are various ICT facilities in special libraries that are not fully functional. The following ICT facilities are: library software, inadequate funding and high cost of maintenance of ICT facilities. It is worthy to note that library software is not functioning in most the special libraries in the country. This confirms the assertion made by Igwesi, Nwachukwu and Chimah (2010) that it is imperative to choose a library oriented, good quality software package carefully in order to ensure effective performance.

After the procurement of the Information and Communication Technologies, there are still thoughts and actions on expenditure towards the installation and continuous maintenance of the facilities. Omekwu (2004) also pointed out that initial investment in system study, design, implementation, procurement of hardware and software could be very expensive. The issue of continuous maintenance has to be taken seriously because if the facilities are not properly maintained, they would not last long. The facilities would then develop faults, and money would have to be spent on the professionals who are in charge of the repairs. If these professionals recommend purchasing new equipment, the library will have no choice but to buy another, thus indirectly creating excessive spending for the library, meanwhile, they are under the budget/funding given by their organization. All these can be avoided with continuous maintenance.

\section{Research Method}

The design used for this study was a survey research method. The reason for this method of research is to examine the application of information and communication Technology in Dissemination of Information in selected Ilorin special libraries having used a quantitative approach. The population for this study comprised of Professional (Librarians) and Para Professionals (Library Assistants, Library Officers,) in three selected libraries which includes: Central Bank of Nigeria Library, Ghalib Chamber Library and Michael Imoudu Institute of Labour Studies Library which are special libraries in the Ilorin Metropolis, Kwara State. The reason for choosing these libraries are the fact that, these institute / organization have a befitting special library that serve their subject in information technology in the metropolis. The estimated number of Professional and Paraprofessional staff in the three selected libraries are shown Table 1.0.

Table 1. Number Of Professional And Paraprofessional Library Staff

NAME OF SPECIAL LIBRARY NO. OF LIBRARY STAFF

\begin{tabular}{lc}
\hline Central Bank of Nigeria Library, Ilorin & 2 \\
Michael Imoudu Institute of Labour Studies, Ilorin & 11
\end{tabular}


Therefore, the sample size for this study constitutes all the library staff (Professionals and Paraprofessionals), representing $100 \%$ of the population. This means that all the twenty-one (21) library staff in the selected special libraries formed the sample size using enumerative technique. In other words, total enumeration sampling technique was used. This was because the population is small and to have a reliable data. A questionnaire was developed to collect data for the study. The questionnaire tagged "Application of Information and Communication Technology in the Dissemination of Information in Special Libraries in Ilorin (A-ICT-DISIKS)", was divided into two main sections. The first Section entails the staff demographic information, while the second section comprises of different items and variables that are contained in the research objectives/questions of the study. The descriptive analysis was used to analyze the collected data using frequency table counts and percentages.

\section{Discussion}

Table 2. Demographics of Respondents

\begin{tabular}{llll}
\hline Demographics & & Frequency & Percent $(\%)$ \\
\hline Gender & Male & 12 & 57.1 \\
\multirow{3}{*}{ Age Bracket } & Female & 9 & 42.9 \\
& <25 years & 6 & 28.6 \\
& 26-35 years & 7 & 33.3 \\
& 36-45 years & 5 & 23.8 \\
Years of Working Experience & $>$ 45 years & 3 & 14.3 \\
& 1-5 years & 10 & 47.6 \\
& 6-10 years & 5 & 23.8 \\
& 11-15 years & 3 & 14.3 \\
& 16-20 years & 1 & 4.80 \\
& $>$ 20 years & 2 & 9.50 \\
\hline
\end{tabular}

Source: Author Field Work, (2019)

Table 1 shows the response on distribution of respondents on gender, age brackets, and years of working experience. In the gender category, Male gender has a count of 12 which is equivalent to $57.1 \%$ of the total population, while the female gender has 8 frequency counts representing $42.9 \%$. In terms of age brackets, $6(28.6 \%)$ of the respondents are less than 25 years, while those within 2635 years are 7 (33.3\%). Similarly, 5 (23.8\%) of them are within 36-45 years of age, while $3(14.3 \%)$ of them are above 45 years. In terms of the years of working experience of the respondents in their various libraries, it was gathered that those that have between 1-years of working experience are 10 (47.6\%); those within 6-10 years are 5 (23.8\%); those that have experience between 11-15 years have counts of $3(14.3 \%)$. Only one of the respondents has $16-20$ years of experience while $2(9.5 \%)$ of them have above 20 years of working experience. The foregoing demographic data show that they're more male gender's response than the female gender. In the same vein, more of the respondents are between 25-35 years while the majority of the respondents have 1-years of experience. 
Mohammed Lawal Akanbi I Application of Information and Communication Technology (ICT) in Information Dissemination in Special Libraries in Nigeria

\section{Analysis of Research Question}

Research Question 1: What is the level of application of ICT on the dissemination of information in the selected special libraries in Ilorin, Kwara state?

Table 3. Distribution of Respondents on Level of ICT Application in the dissemination of information

Note: $\mathrm{SA}=$ strongly agree, $\mathrm{A}=$ agree, $\mathrm{D}=$ disagree, $\mathrm{SD}=$ strongly disagree

\begin{tabular}{|c|c|c|c|c|}
\hline Level of ICT Application & $\overline{\text { SA }}$ & $\mathbf{A}$ & D & SD \\
\hline $\begin{array}{l}\text { ICT in our library helps to integrate the library } \\
\text { services with the library users }\end{array}$ & $10(47.6 \%)$ & $9(42.9 \%)$ & $1(4.8 \%)$ & $1(4.8 \%)$ \\
\hline $\begin{array}{l}\text { Our Research and Development is more of } \\
\text { ICT oriented }\end{array}$ & $3(14.3 \%)$ & $11(52.4 \%)$ & $7(33.3 \%)$ & $0(0.0 \%)$ \\
\hline $\begin{array}{l}\text { Most of the services we rendered to the staff } \\
\text { and other library users are done using some } \\
\text { ICT tools }\end{array}$ & $2(9.5 \%)$ & $10(47.6 \%)$ & $7(33.3 \%)$ & $2(9.5 \%)$ \\
\hline $\begin{array}{l}\text { Our users can have access to some of our } \\
\text { resources within their comfort using mobile } \\
\text { phones, computer, and related devices }\end{array}$ & $3(14.3 \%)$ & $8(38.1 \%)$ & $9(42.9 \%)$ & $1(4.8 \%)$ \\
\hline $\begin{array}{l}\text { Internet facility is available in the library for } \\
\text { library users as well as for the library staff }\end{array}$ & $2(9.5 \%)$ & $9(42.9 \%)$ & $6(28.6 \%)$ & $4(19.0 \%)$ \\
\hline $\begin{array}{l}\text { The library, rendered Current Awareness } \\
\text { Service uses some ICT tools like Email, } \\
\text { Usenet, etc. }\end{array}$ & $4(19.0 \%)$ & $5(23.8 \%)$ & $8(38.1 \%)$ & $4(19.0 \%)$ \\
\hline $\begin{array}{l}\text { Selective Dissemination of Information (SDI) } \\
\text { is always done with the aid of technological } \\
\text { tools }\end{array}$ & $0(0.0 \%)$ & $5(23.8 \%)$ & $14(66.7 \%)$ & $2(9.5 \%)$ \\
\hline Our library is fully automated & $1(4.8 \%)$ & $2(9.5 \%)$ & $14(66.7 \%)$ & $4(19.0 \%)$ \\
\hline $\begin{array}{l}\text { We make use of Online Public Access } \\
\text { Catalogue (OPAC) which can be accessible } \\
\text { anytime, anywhere }\end{array}$ & $1(4.8 \%)$ & $5(23.8 \%)$ & $11(52.4 \%)$ & $4(19.0 \%)$ \\
\hline $\begin{array}{l}\text { Reprographic ICT tools like scanner, } \\
\text { photocopying machine, and printer are } \\
\text { available for library users }\end{array}$ & $8(38.1 \%)$ & $6(28.6 \%)$ & $7(33.3 \%)$ & $0(0.0 \%)$ \\
\hline
\end{tabular}

Source: Author Field Work, (2019)

Table 3 shows the distribution of respondent on the level of applying ICT, especially for dissemination of information to $10(47.6 \%)$ of respondents strongly agree that ICT in their library helps to integrate the library services with the library users. 8 (42.9\%) of them agree; while $1(4.8 \%)$ each disagree and strongly disagree. Similarly, 3 (14.3) strongly agree that their research and development practice in the library is ICT oriented and $11(52.4 \%)$ of them agree; while $7(33.3 \%)$ disagree and none of them strongly disagree. Based on the services rendered, $2(9.5 \%)$ of the respondents strongly agree that most of the services rendered in their respective libraries are done using some ICT tools. In addition, 10 (47.6\%) agree and 7 (33.3\%) disagree while 2 (9.5\%) strongly disagree with this. Subsequently, $3(14.3 \%)$ strongly agree that users can have access to some of our resources within their comfort using mobile phones, computer, and related devices; $8(38.1 \%)$ agree; $9(42.9 \%)$ disagree and $1(4.8 \%)$ strongly disagree. With the availability of internet facility for library users, 2 (9.5\%) strongly agree; 9 (42.9\%) agree; 6 (28.5\%) disagree while 4 (19.0\%).

Furthermore, $4(19.0 \%)$ strongly agree the library, rendered current awareness service using some ICT tools like email, Usenet. $5(23.8 \%)$ of them agree; while $8(38.1 \%)$ disagree and $4(19.0 \%)$ strongly disagree. None of the respondents strongly agree that selective dissemination of information 
(SDI) is always done with the aid of technological tools; 5 (23.8\%) of them agree; while 14 (66.7\%) disagree and $2(9.5 \%)$ strongly disagree. Based on automation, $1(4.8 \%)$ of the respondents strongly agree that their library is fully automated. Also, 2 (9.5\%) agree; 14 (66.7\%) disagree while 4 (19.0\%) strongly disagree with this. Also, 1 (4.8\%) strongly agree" that they make use of the online public access catalogue (OPAC) which can be accessible anytime, anywhere; 5 (23.8\%) agree; 11 (52.4\%) disagree and 4 (19.0\%) strongly disagree. On the availability of reprographic ict tools like scanner, photocopying machine, and printer for library users, 8 (38.1\%) strongly agree; 6 (28.6\%) agree; while $7(33.3 \%)$ disagreed. None of the respondents strongly disagree to the statement.

Research Question 2: What are the efficiencies and effectiveness of ICT on the dissemination of information in the selected special libraries?

Table 4. Distribution of Respondents on Efficiency and Effectiveness of ICT in the dissemination of information

Note: $\mathrm{SA}=$ strongly agree, $\mathrm{A}=$ agree, $\mathrm{D}=$ disagree, $\mathrm{SD}=$ strongly disagree

\begin{tabular}{|c|c|c|c|c|}
\hline Efficiency and Effectiveness of ICT & $\mathbf{S A}$ & $\mathbf{A}$ & $\mathbf{D}$ & SD \\
\hline $\begin{array}{l}\text { Taking record of library users is now so easy } \\
\text { with the application of some ICT facilities }\end{array}$ & $8(38.1 \%)$ & $8(38.1 \%)$ & $5(23.8 \%)$ & $0(0.0 \%)$ \\
\hline $\begin{array}{l}\text { Most of referral services done in the library } \\
\text { are fast and reliable }\end{array}$ & $7(33.3 \%)$ & $8(38.1 \%)$ & $6(28.6 \%)$ & $0(0.0 \%)$ \\
\hline $\begin{array}{l}\text { Reprographic ICT tools have made } \\
\text { information dissemination to be easier }\end{array}$ & $9(42.9 \%)$ & $5(23.8 \%)$ & $6(28.6 \%)$ & $1(4.8 \%)$ \\
\hline $\begin{array}{l}\text { The availability of Internet for library users } \\
\text { has reduced the workload on librarians }\end{array}$ & $4(19.0 \%)$ & $9(42.9 \%)$ & $7(33.3 \%)$ & $1(4.8 \%)$ \\
\hline $\begin{array}{l}\text { The library carries out Current Awareness } \\
\text { Services (CAS) }\end{array}$ & $3(14.3 \%)$ & $9(42.9 \%)$ & $8(38.1 \%)$ & $1(4.8 \%)$ \\
\hline $\begin{array}{l}\text { Users of the library have access to library } \\
\text { databases and E-resources which have more } \\
\text { resources credibility than some printed books }\end{array}$ & $0(0.0 \%)$ & $10(47.6 \%)$ & $9(42.9 \%)$ & $2(9.5 \%)$ \\
\hline
\end{tabular}

Source: Author Field Work, (2019)

Table 4 shows the distribution of respondent received on the efficiency and effectiveness of ICT in the dissemination of information with $8(38.1 \%)$ each strongly agrees and agree respectively that taking record of library users is now so easy with the application of some ICT facilities; while 5 (23.7\%) disagree and none of them strongly disagree. Also 7 (33.3\%) strongly agree that most of referral services done in the library is fast and reliable; $8(38.1 \%)$ of them agree; $6(28.6 \%)$ disagree while none of them strongly disagree.

On the application of reprographic ICT tools as (Table 4.0), 9 (42.9\%) of the respondents strongly disagree reprographic ICT tools have made information dissemination to be easier; 5 (23.8\%) agree; while 6 (28.6\%) disagree and 1 (4.8\%) strongly disagree. Subsequently, 4 (19.0\%) strongly agree that the availability of internet for library users has reduce the workload on librarians; $9(42.9 \%)$ agree; $7(33.3 \%)$ disagree while 1 (4.8\%) strongly disagree with this. On whether the library carries out current awareness services (CAS), 3 (14.3\%) strongly agree; 9 (42.9\%) agree; 8 (38.1\%) disagree while $1(4.8 \%)$ strongly disagree. Also, $10(47.6 \%)$ agree that users of their library have access to library databases and e-resources which have more resources, credibility than some printed books; 9 (42.9\%) disagree with this while $2(9.5 \%)$ strongly disagree.

Research Question 3: What are the contributions of ICT to the provision of information about the selected special libraries in Ilorin, Kwara state?

Akanbi, M. L., Ogunleye, D. O., \& Sulaiman, K. A. (2020). Application of Information and Communication

Technology (ICT) in Information Dissemination in Special Libraries in Nigeria. Record and Library Journal, $6(1), 1-13$.

Open access under Creative Commons Attribution-Share A like 4.0 International Licence

(CC BY-SA) @( () () 
Mohammed Lawal Akanbi I Application of Information and Communication Technology (ICT) in Information Dissemination in Special Libraries in Nigeria

Table 5. Distribution of Respondents on the Contribution of ICT in the Provision of Information Note: $\mathrm{SA}=$ strongly agree, $\mathrm{A}=$ agree, $\mathrm{D}=$ disagree, $\mathrm{SD}=$ strongly disagree

\begin{tabular}{lcccc}
\hline $\begin{array}{c}\text { Contribution of ICT in the } \\
\text { Provision of Information }\end{array}$ & SA & A & D & D \\
\hline Acquisition of Information Materials & $8(38.1 \%)$ & $9(42.9 \%)$ & $4(19.0 \%)$ & $0(0.0 \%)$ \\
Selection of Information Materials & $7(33.3 \%)$ & $9(42.9 \%)$ & $5(23.8 \%)$ & $0(0.0 \%)$ \\
Processing of Information Materials & $5(23.8 \%)$ & $10(47.6 \%)$ & $6(28.6 \%)$ & $0(0.0 \%)$ \\
Library Consortium & $3(14.3 \%)$ & $11(52.4 \%)$ & $7(33.3 \%)$ & $0(0.0 \%)$ \\
Organization of Information Materials & $5(23.8 \%)$ & $10(47.6 \%)$ & $6(28.6 \%)$ & $0(0.0 \%)$ \\
$\begin{array}{l}\text { Dissemination of Information } \\
\text { Materials }\end{array}$ & $4(19.0 \%)$ & $12(57.1 \%)$ & $4(19.0 \%)$ & $1(4.8 \%)$ \\
Tracking Record of Library users & $4(19.0 \%)$ & $13(61.9 \%)$ & $2(9.5 \%)$ & $2(9.5 \%)$ \\
\hline
\end{tabular}

Source: Author Field Work, (2019)

Table 5 indicates the distribution of respondent on the contribution of ICT in the provision of information. Out of all the respondents, 8 (38.1\%) strongly agree that ICT contribute to the acquisition of information materials; 9 (42.9\%) of them agree; 4 (19.0) disagree while none of them strongly disagree. For selection of information, materials, 7 (33.3\%) strongly agree; 9 (42.9\%) agree; while the remaining 5 (23.8\%) disagree. Responses on the use of ICT for processing has a count of $5(23.8 \%)$ for strongly agree; $10(47.6 \%)$ for agree and the remaining $6(28.6 \%)$ for disagree. Similarly, on the use of ICT for library consortium, there was a count of $3(14.3 \%)$ for strongly agree; $11(52.4 \%)$ for agree and the remaining $7(33.3 \%)$ for disagree. For organization of information materials with ict, $5(23.8 \%)$ strongly agree; 10 (47.6\%) for agree and the remaining $6(28.6 \%)$ for disagree. For the dissemination of information using ict, 4 (19.0\%) strongly agree; $12(57.1 \%)$ agree; $4(19.0 \%)$ disagree. While only $1(4.8 \%)$ strongly disagree. On the use of ICT to track record of library users, 4 (19.0\%) of the respondents strongly agree; $13(61.9 \%)$ agree; while 2 (9.5\%) each disagree and strongly disagree respectively.

From the foregoing results, it can be concluded that the respondents are aware of the great contributions of ICT in library routines such as acquisition, selection, organization, dissemination of information, library consortium and in tracking of library users' record. It is, however unfortunate that they do not make use of these fully despites their awareness about the importance of ICT. Though, it established that these libraries make their selection and acquisition process through ICT and make information dissemination or dispatch to sister institutions and libraries through ICT.

Research Question 4: What are factors that promote the use of ICT based equipment on the selected special libraries in Ilorin, Kwara

Table 6. Distribution of Respondents on the Factors that Promotes the Use of ICT

Note: $\mathrm{SA}=$ strongly agree, $\mathrm{A}=$ agree, $\mathrm{D}=$ disagree, $\mathrm{SD}=$ strongly disagree

\begin{tabular}{lcccc}
\hline Factors that Promotes the Use of ICT & SA & A & D & SD \\
\hline Orientation of the management & $6(28.6 \%)$ & $11(52.4 \%)$ & $3(14.3 \%)$ & $1(4.8 \%)$ \\
$\begin{array}{l}\text { Attitude of Library Users } \\
\text { Types of Resources }\end{array}$ & $4(19.0 \%)$ & $12(57.1 \%)$ & $4(19.0 \%)$ & $1(4.8 \%)$ \\
$\begin{array}{l}\text { Nature of Research and Development } \\
\text { on the institution }\end{array}$ & $5(23.8 \%)$ & $13(61.9 \%)$ & $3(14.3 \%)$ & $0(0.0 \%)$ \\
\end{tabular}

To cite this document:

Akanbi, M. L., Ogunleye, D. O., \& Sulaiman, K. A. (2020). Application of Information and Communication

Technology (ICT) in Information Dissemination in Special Libraries in Nigeria. Record and Library Journal, $6(1), 1-13$.

Open access under Creative Commons Attribution-Share A like 4.0 International Licence

(CC BY-SA) @ (ब) 
Mohammed Lawal Akanbi I Application of Information and Communication Technology (ICT) in Information Dissemination in Special Libraries in Nigeria

Source: Author Field Work, (2019)

Table 6 shows the response on distribution of the factors which could promote the use of ICT in special libraries indicated that $6(28.6 \%)$ strongly agree that orientation of the management is a great factor that promote the use of ICT while $11(52.4 \%)$ agree; $3(14.3 \%)$ disagree and $1(4.8 \%)$ strongly disagree. Similarly, an attitude of library users, 4 (19.0\%) strongly agree while $12(57.1 \%)$ agree; $4(19.0 \%)$ disagree and $1(4.8 \%)$ strongly disagree. On whether the nature of research and development of the institution is a factor that promote the use of ict, $5(23.8 \%)$ strongly agree; 11 $(52.4 \%)$ of them agree while the remaining 5 (23.8\%) disagree. From all indications, it could be inferred that "types of resources" and "orientation of management" are the two major factors that can promotes the use of ICT.

Research Question 5: What are the challenges associated with the application of ICT in the special libraries in Ilorin, Kwara state?

Table 7. Distribution of Respondent on the Challenges associated with the Application of ICT use in a Special Library

Note: $\mathrm{SA}=$ strongly agree, $\mathrm{A}=$ agree, $\mathrm{D}=$ disagree, $\mathrm{SD}=$ strongly disagree

$\begin{array}{lllll}\text { Challenges associated with the } & \text { SA } & \text { A } & \text { D } & \text { SD }\end{array}$
Application of ICT

\begin{tabular}{lllll}
\hline Poor electricity & $10(47.6 \%)$ & $5(23.8 \%)$ & $4(19.0 \%)$ & $2(9.5 \%)$ \\
Slow internet connectivity & $10(47.6 \%)$ & $9(42.9 \%)$ & $1(4.8 \%)$ & $1(4.8 \%)$ \\
Poor library settings & $7(33.3 \%)$ & $5(23.8 \%)$ & $7(33.3 \%)$ & $2(9.5 \%)$ \\
Insufficient information materials & $5(23.8 \%)$ & $5(23.8 \%)$ & $9(42.9 \%)$ & $2(9.5 \%)$ \\
Lackadaisical attitude of the library staff & $6(28.6 \%)$ & $4(19.0 \%)$ & $8(38.1 \%)$ & $3(14.3 \%)$ \\
High workload & $4(19.0 \%)$ & $5(23.8 \%)$ & $11(52.4 \%)$ & $1(4.8 \%)$ \\
Poor information retrieval skill & $5(23.8 \%)$ & $6(28.6 \%)$ & $8(38.1 \%)$ & $2(9.5 \%)$ \\
\hline
\end{tabular}

Source: Author Field Work, 2019

Table 7 shows the distribution of respondents on the challenges faced in the application of ICT with a majority of respondents identified slow internet connectivity as a major problem. This is followed by poor electrical; poor library settings, and poor information retrieval skill. High workload, the lackadaisical attitude of library staff, and insufficient information materials were not part of the major challenges faced in the application of ICT.

\section{Analysis and Discussion}

On the level of application of ICT in the dissemination of information in the selected special libraries. The study reveals that ICT helps in integrating library services to the library users, library services rendered to the staff and other library users are done using ICT tools, selective dissemination of information (SDI) is always done with the aid of technological tools, the library, rendered current awareness service (CAS) using some ICT tools like email, Usenet, OPAC is used to access and anytime. The finding is supported by Mamman, (2015) that the application of ICT in special library operations also reduces the tedious and energy-sapping tasks associated with manual operations in the library.

On the efficiencies and effectiveness of ICT in the dissemination of information on the selected special libraries. The study reveals that taking record of library users is now so easy with the application of some ICT, referral services done in the library very fast, reprographic ICT tools

Akanbi, M. L., Ogunleye, D. O., \& Sulaiman, K. A. (2020). Application of Information and Communication

Technology (ICT) in Information Dissemination in Special Libraries in Nigeria. Record and Library Journal, $6(1), 1-13$.

Open access under Creative Commons Attribution-Share A like 4.0 International Licence

(CC BY-SA) @( () (2) 
have made information dissemination to be easing, the availability of Internet for library users has reduced the workload on librarians and users of the library have access to library databases and eresources which have more resources credibility than some printed books. The finding of this study is in line with Madu and Azubogu (2017) that ICT has to be made an addition to special libraries and a critical component towards supporting the provision of effective information services to the parent organization.

The finding of this study also reveals that ICT has greatly influenced the acquisition, selection, processing, library consortium, organization, dissemination and tracking record of library users in the library. Ramzan and Singh (2009) support that's easy integration of various library activities, increases efficiency in the acquisition, access to data, cataloguing, classification, information retrieval and dissemination.

The study also reveals that orientation, attitude, types of resources and nature of research and development in the institution are factors that promote or hinder the use of ICT based equipment on the selected special libraries. The study also reveals that poor electricity, slow internet connection, insufficient, poor library settings, lackadaisical attitude, high workload and poor information retrieval skill are challenges associated with the application of ICT. Ani (2005) supported that the level of funding of libraries and their ICT budgets in Nigeria is comparatively low and thus affect the application of ICT in a special library.

\section{Conclusion}

Technology has turned out to be one of the major drivers in many sectors and institutions. Many libraries, especially special libraries now make use of Information and Communication Technology (ICT) related gadgets to facilitate operations. Consequent on how ICT drives operations in special libraries, this research project understudied "Application of ICT in Dissemination of Information in Selected Special Libraries in Ilorin Metropolis". The special libraries studied were Central Bank of Nigeria, Ghalib Chamber Library and Michael ImouduInstitute of Labor Studies Library. In order to ascertain application of ICT in the dissemination of Information in the understudied libraries, the objectives formulated were to: know the level of application of information communication technology in the dissemination of information; identify the specific factors that promote or hinder the use of ICT based equipment; determine the efficiency and effectiveness of ICT in the dissemination of information in special libraries; assess the contribution of ICT in the provision of information and to determine the challenges associated with the application of ICT in these special libraries. These objectives were achieved using a selfadministered questionnaire as an instrument. Based on the data collected, the following are the key findings of the study:

a. There is a limited number of staff working in special libraries in Ilorin

b. ICT facility is available in the libraries but not fully adopted and used for some library services like SDI, CAS, etc.

c. Low use of ICT makes library operation not to be effective and efficient as expected.

d. Users of the libraries rarely have access to library databases and E-resources which have more resources credibility than some printed books

e. The orientation of the management, attitude of library users, types of resources and nature of Research and Development in the institutional libraries are the key factors that can promote ICT usage

f. Hindrances faced in the use of the limited ICT available are poor internet connection; power outage, inadequate information retrieval skills.

Akanbi, M. L., Ogunleye, D. O., \& Sulaiman, K. A. (2020). Application of Information and Communication

Technology (ICT) in Information Dissemination in Special Libraries in Nigeria. Record and Library Journal, 
Mohammed Lawal Akanbi I Application of Information and Communication Technology (ICT) in Information Dissemination in Special Libraries in Nigeria

\section{References}

Asghar, Mahe, B. \&Shafique, F. (2012). Service Evaluation in Special Libraries of Bahawalpur: A Comparative Study of GCT, QMC, and UCET, Library Philosophy and Practice. Retrieved from http://digitalcommons.unl.edu/libphilprac/822

Bilawar, P.B. (2013). Statement on Library and Information Services Staff Appointments American International Journal of Research in Humanities; Arts and Social Sciences, 3(2), 134-140

Bitagi, A.M. (2013). "Information Resources Utilization for Research by Scientists in Agricultural Research Institutes in Nigeria". Seminar presented at the Faculty of Education, University of Nigeria, Nsukka, Enugu State.

Brey, P. (2009). Philosophy of Technology Meets Social Constructivism: A Shopper's Guide.In Readings in the Philosophy of Technology, $2^{\text {nd }}$ ed. Edited by David M. Kaplan. Lanham: Rowman\& Littlefield Publishers, 268-324.

Chandler, D., Daniel, H.,\&Munday, H. \& Rod, T.(2012). “definitions of ICT”. Retrieved fromhttps://www.google.com.ng/amp/s/collegeassignments.wordpress.com/2012/10/01/provide-fivedefinitions-of-ict/it-indicate-the-author-and-year-what-are-the-similarities-and-differences-in-thesedefinitions-provide-your-own-definition-of-ict/it/amp/

Daintith, J. (2009). A Dictionary of Physics, Oxford University Press. Retrieved from https://www.revolvy.com/page/Information-technology.

Ifueko, O.O. (2011). The Impact of Information and Communication Technology (ICT) in Nigerian University Libraries. LibraryPhilosophyandPractice(e-journal). Retrieved from https://digitalcommons.unl.edu/libphilprac/583/

Igwesi, U., Nwachukwu, V. N. \&Chimah, J. N. (2010). Software choice and use in libraries: Requirements for effective computer application in University Libraries in Nigeria. A paper presented at the state conference and AGM of the Nigerian library association, Benue state,June, $17 \& 18$.

Made R. H., \& Azubogur, C. K. (2017). ICT Infrastructure in University Libraries in Karnataka. Annals of Library and information studies, 56, 236-241.

Madu, E.C. (2004). Automation and Service provision in libraries and Information Centre in developing countries, in Madu C. (Ed) Technology for Information Management and services. Ibadan: E Nicole man publication, 45-54.

Madu, C.C. \&Azubogu, N. (2017).Impact of the application of Information and Communication on Information dissemination in selected libraries of Federal Universities in South-South Nigeria.Project topic submitted to the department of Library and Information science, University of Ilorin

Make, J.N. (2008). Analysis of University undergraduate students' and lecturers' needs for the information age: Implications for teaching and learning. Proceedings of first international conference of the faculty of Education, University of Nigeria Nsukka.

Mamman, E.S. (2015).Utilization of Information and Communication Technologies (ICTs) in Public Library Services in Nigeria(Unpublished doctoral dissertation), University of Nigeria, Nsukka, Enugu, Nigeria.

Murray, T. E. (2013). The Specialist. Journal of Library Administration. 53 (1), 274-282.

Okenwa, G.N. (2008). Meeting the Challenges of Information Technology: A case for reform in distance education programme.Proceedings of first International conference of the faculty of Education, University of Nigeria Nsukka,

Rana, H.K. (2009). Impact of Information and Communication Technology on Academic Libraries in Punjab. Journal of Library and Information Sciences, 4(1),56-63

Ramzan, M. \&Singh, D. (2009). Status of Information Application in Pakistan libraries.The Electronic Library 27(4), 573-587.

Routledge, T. (1997). International Encyclopedia of Information and Library Science. Feather John \&Sturges, Paul (Eds), $2{ }^{\text {nd }}$ Ed. New York: Routledge.

To cite this document:

Akanbi, M. L., Ogunleye, D. O., \& Sulaiman, K. A. (2020). Application of Information and Communication

Technology (ICT) in Information Dissemination in Special Libraries in Nigeria. Record and Library Journal, 6(1), 1-13.

Open access under Creative Commons Attribution-Share A like 4.0 International Licence

(CC BY-SA) @ () () 
Mohammed Lawal Akanbi I Application of Information and Communication Technology (ICT) in Information Dissemination in Special Libraries in Nigeria |

Volti, R. (2009). Society and Technological Change, $7^{\text {th }}$ Ed. New York: Worth Publishers.

Williams, R.V. (2007). Special Libraries Management Handbook: The Basics. Retrieved from,http://www.libsci.sc.edu/bob/class/clis724/SpecialLibrariesHandbook?INDEX.htmwww.futalib .wordpress.com/2013/01/13/use-of-information-and-communication-technology-ict-in-the-librarylibrary-automation/

To cite this document:

Akanbi, M. L., Ogunleye, D. O., \& Sulaiman, K. A. (2020). Application of Information and Communication Technology (ICT) in Information Dissemination in Special Libraries in Nigeria. Record and Library Journal, 6(1), 1-13.

Open access under Creative Commons Attribution-Share A like 4.0 International Licence 